\title{
Catalytic C-H Bond Activation at Nanoscale Lewis Acidic Aluminium Fluorides: H/D Exchange Reactions at Aromatic and Aliphatic Hydrocarbons
}

\author{
Martin H. G. Prechtl, Michael Teltewskoi, Anton Dimitrov, Erhard Kemnitz, * and \\ Thomas Braun*[a]
}

Isotope labeling reactions play a fundamental role in pharmaceutical, medical and spectroscopic applications. ${ }^{[1-6]}$ For example, deuterated and tritiated compounds are used as labeling entities in NMR spectroscopy, for drug development and for studies of metabolism processes. ${ }^{[7,8]}$ Deuterated markers are also considered for the identification of illegally mixed diesel oil. ${ }^{[9,10]}$ Moreover, deuterated compounds have become increasingly attractive for material science. Thus deuterated polymers can be superior in comparison to their non-deuterated counterparts, that is in organic lightemitting diodes (OLEDs) and for optical communication or high-speed telecommunication systems. ${ }^{[11-13]}$ In general, these aspects result in an increasing interest in the development of mild catalytic deuterium-labeling processes.

H/D exchange processes are frequently performed with deuterium sources such as $\left[\mathrm{D}_{6}\right]$ benzene or $\left[\mathrm{D}_{6}\right]$ acetone, deuterated alcohols and in some cases with deuterium oxide. $^{[1,3,6-8,14-18]}$ To achieve a hydrogen/deuterium exchange at $\mathrm{C}-\mathrm{H} / \mathrm{D}$ bonds under mild conditions, powerful molecular or nanoscale catalyst materials are usually required. ${ }^{[16,17,19-25]}$ For effective conversions often precious and expensive transition-metal catalysts, such as organometallic complexes, metal nanoparticles or metals on carbon or alumina support, are needed. ${ }^{[1,3,6-8,14-18,20,21,24]}$

$\mathrm{H} / \mathrm{D}$ exchange reactions at alkanes have been described in liquid superacids at low temperature,${ }^{[26,27]}$ at platinum catalysts of the Shilov or Periana type as well as at precious metals/C being active within a temperature range of 160 $250^{\circ} \mathrm{C} .^{[9,15,28-30]}$ Non-transition-metal catalysts for the efficient deuteration of alkanes are rare. Lewis acidic zeolites promote the H/D exchange between branched alkanes at temperatures $>150{ }^{\circ} \mathrm{C}$. The substrate loadings and conversions are usually low, even after prolonged reaction times. ${ }^{[31-37]}$ However, dehydroxylated metal oxides, especially $\gamma-\mathrm{Al}_{2} \mathrm{O}_{3}$, catalyse $\mathrm{H} / \mathrm{D}$ exchange, for example, at methane,

[a] Dr. M. H. G. Prechtl, Dipl.-Chem. M. Teltewskoi, Dr. A. Dimitrov, Prof. Dr. E. Kemnitz, Prof. Dr. T. Braun

Humboldt-Universität zu Berlin, Department of Chemistry

Brook-Taylor-Strasse 2, 12489 Berlin (Germany)

E-mail: erhard.kemnitz@chemie.hu-berlin.de thomas.braun@chemie.hu-berlin.de

Supporting information for this article is available on the WWW under http://dx.doi.org/10.1002/chem.201102853. at room temperature, when treated beforehand at $400^{\circ} \mathrm{C}^{[38]}$ Lewis acids such as $\mathrm{AlBr}_{3}, \mathrm{EtAlCl}_{2}$ or $\mathrm{MoCl}_{5}$ catalyse efficiently the $\mathrm{H} / \mathrm{D}$ exchange between arenes, only. ${ }^{[7,8]}$

We report herein a new catalytic procedure for efficient $\mathrm{H} / \mathrm{D}$ exchange reactions at aliphatic and aromatic $\mathrm{C}-\mathrm{H} / \mathrm{D}$ bonds. Solid nanoscopic Lewis acids as catalysts enable the generation of deuterated alkanes and benzene at mild conditions. The Lewis acids aluminium chlorofluoride $\left(\mathrm{Al}_{1.0} \mathrm{Cl}_{0.13} \mathrm{~F}_{2.87} ; \mathrm{ACF}\right)^{[39,40]}$ and high-surface aluminium trifluoride ( $\left.\mathrm{HS}-\mathrm{AlF}_{3}\right)^{[41-43]}$ are both capable of the activation of $\mathrm{C}-\mathrm{H} / \mathrm{D}$ bonds at temperatures between $40^{\circ} \mathrm{C}$ and $110^{\circ} \mathrm{C}$.

A solution of cyclohexane $(0.95 \mathrm{mmol})$ in $\mathrm{C}_{6} \mathrm{D}_{6}(0.5 \mathrm{~mL}$, $5.65 \mathrm{mmol})$ led in the presence of $\mathrm{HS}-\mathrm{AlF}_{3}(0.5 \mathrm{mmol}$; molar ratio $\mathrm{C}-\mathrm{H}$ bonds:catalyst $=23$ ) at $110^{\circ} \mathrm{C}$ within $22 \mathrm{~h}$ to the formation of deuterated cyclohexane and methylcyclopentane (ratio: 88:12 based on GC-MS measurements). We found a conversion of $34 \%$ by NMR analysis, that is $34 \%$ of the alkane $\mathrm{C}-\mathrm{H}$ entities have been deuterated (Scheme 1, Figure 1). ACF showed an even higher catalytic activity for the activation of $\mathrm{C}-\mathrm{H} / \mathrm{D}$ bonds. On using $\mathrm{C}_{6} \mathrm{D}_{6}$ as deuterium source a conversion of $63 \%$ for the incorporation of deuterium into the alkane products was obtained at $110^{\circ} \mathrm{C}$ (Figure 1, molar ratio $\mathrm{C}-\mathrm{H}$ bonds: catalyst $=23$ ). With ACF the product distribution of deuterated cyclohexane and methylcyclopentane is similar to that one found in $\mathrm{HS}-\mathrm{AlF}_{3}$. Even lower loadings with $\mathrm{ACF}$ as a catalyst revealed a high degree of alkane deuteration with activities similar to those that have been found with $\mathrm{HS}-\mathrm{AlF}_{3}$ at a higher catalyst loading (Figure 1).

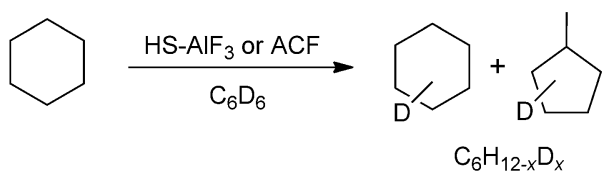

Scheme 1. H/D exchange reactions between $\mathrm{C}_{6} \mathrm{D}_{6}$ and $\mathrm{C}_{6} \mathrm{H}_{12}$.

In contrast, commercial ultra-dry $\mathrm{AlCl}_{3}$ does not activate a $\mathrm{C}-\mathrm{H}$ bond in cyclohexane, but aromatic $\mathrm{C}-\mathrm{H}$ bonds in toluene were activated in $\mathrm{C}_{6} \mathrm{D}_{6}$ solution $\left(>80 \%\right.$ conversion). ${ }^{[44]}$ This behaviour can be explained by the solubility of $\mathrm{AlCl}_{3}$ in neat aromatic solvents but its insolubility in alkanes. ${ }^{[45]}$ 


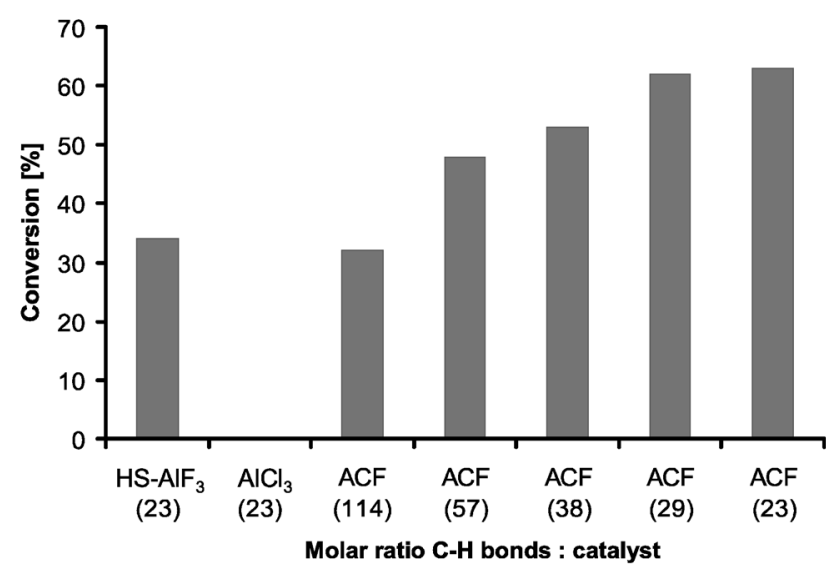

Figure 1. Deuteration (\% conversion) of $\mathrm{C}-\mathrm{H}$ bonds in the alkane products after the $\mathrm{H} / \mathrm{D}$ exchange between $\mathrm{C}_{6} \mathrm{D}_{6}(5.65 \mathrm{mmol})$ and $\mathrm{C}_{6} \mathrm{H}_{12}$ $(0.95 \mathrm{mmol})$ after $22 \mathrm{~h}$ at $110^{\circ} \mathrm{C}$ in the presence of aluminium fluorides (0.1-0.5 mmol).

Thus, we assume that the activation of toluene at $\mathrm{AlCl}_{3}$ is a homogeneous reaction. $\mathrm{HS}-\mathrm{AlF}_{3}$ and $\mathrm{ACF}$ are insoluble in alkanes and aromatic solvents. ${ }^{[45]}$ This is consistent with the occurrence of the carbon-hydrogen bond activation reactions at the surface for the latter fluorides. Note that $\mathrm{AlBr}_{3}$ also solely cleaves $\mathrm{C}-\mathrm{H}$ bonds of arenes, because of its solubility in aromatic solvents..$^{[7,8]}$

The successful deuteration of alkanes by $\mathrm{C}-\mathrm{H}$ activation implies that deuterated alkanes may act themselves as deuterium source. Therefore, we studied the potential of $\left[\mathrm{D}_{12}\right]$ cyclohexane as deuterium source in Lewis acid catalysed H/D exchange reactions with benzene as substrate (Scheme 2). High deuterium incorporation with both ACF

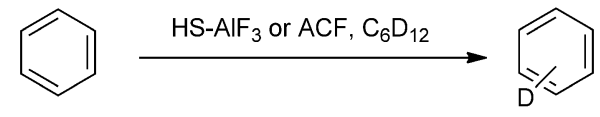

Scheme 2. H/D exchange between $\mathrm{C}_{6} \mathrm{D}_{12}$ and $\mathrm{C}_{6} \mathrm{H}_{6}$.

and $\mathrm{HS}-\mathrm{AlF}_{3}$ as catalysts $(0.5 \mathrm{mmol}$; molar ratio $\mathrm{C}-\mathrm{H}$ bonds : catalyst $=13$ ) was observed at $110{ }^{\circ} \mathrm{C}$ (Figure 2, $86 \%$ conversion, $\left[\mathrm{D}_{12}\right]$ cyclohexane $(4.63 \mathrm{mmol})$ and benzene $(1.12 \mathrm{mmol}))$. Note that methylcyclopentane isomers were formed here, too. The high conversion of aromatic $\mathrm{C}-\mathrm{H}$ into $\mathrm{C}-\mathrm{D}$ bonds can be explained by statistical means. Thus, the $\mathrm{D} / \mathrm{H}$ ratio in the system $\left[\mathrm{D}_{12}\right]$ cyclohexane/benzene is approximately $9: 1$ in comparison to the previous system with $\mathrm{C}_{6} \mathrm{D}_{6}$ as deuterium source (ratio: ca. 3:1). Consequently, we obtained 1.5-2.5 fold higher conversions. In addition, toluene was successfully deuterated with ACF (79\% deuteration of aromatic $\mathrm{C}-\mathrm{H}$ bonds). Here, the deuteration occurred solely at the arene moiety.

Reactions at lower temperatures also led to remarkable high conversions. At $40^{\circ} \mathrm{C}$ and $70^{\circ} \mathrm{C}$ deuterium incorporation into benzene with $65 \%$ and $81 \%$ conversion, respectively, was achieved with $\left[\mathrm{D}_{12}\right]$ cyclohexane as deuterium

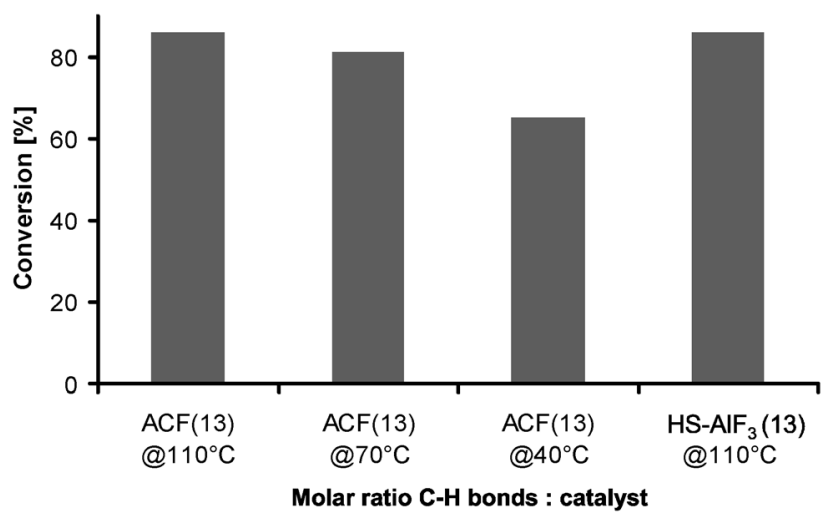

Figure 2. Deuteration (\% conversion) of $\mathrm{C}-\mathrm{H}$ bonds in benzene after the $\mathrm{H} / \mathrm{D}$ exchange between $\mathrm{C}_{6} \mathrm{D}_{12}(4.63 \mathrm{mmol})$ and $\mathrm{C}_{6} \mathrm{H}_{6}(1.12 \mathrm{mmol})$ after $22 \mathrm{~h}$ in the presence of aluminium fluorides $(0.5 \mathrm{mmol})$.

source (Figure 2) and with ACF as catalyst. Experiments with cyclohexane as substrate and $\left[\mathrm{D}_{6}\right]$ benzene as deuterium source were also successful. Conversions of $26 \%$ at $40^{\circ} \mathrm{C}$ (Figure 3 ) and $43 \%$ at $70^{\circ} \mathrm{C}$ were obtained ([D $]$ benzene/cyclohexane ratio $3: 1)$. A higher $\left[\mathrm{D}_{6}\right]$ benzene/cyclohexane ratio $(6: 1)$ led to $56 \%$ alkane $\mathrm{C}-\mathrm{D}$ bonds within $22 \mathrm{~h}$ at $70^{\circ} \mathrm{C}$.

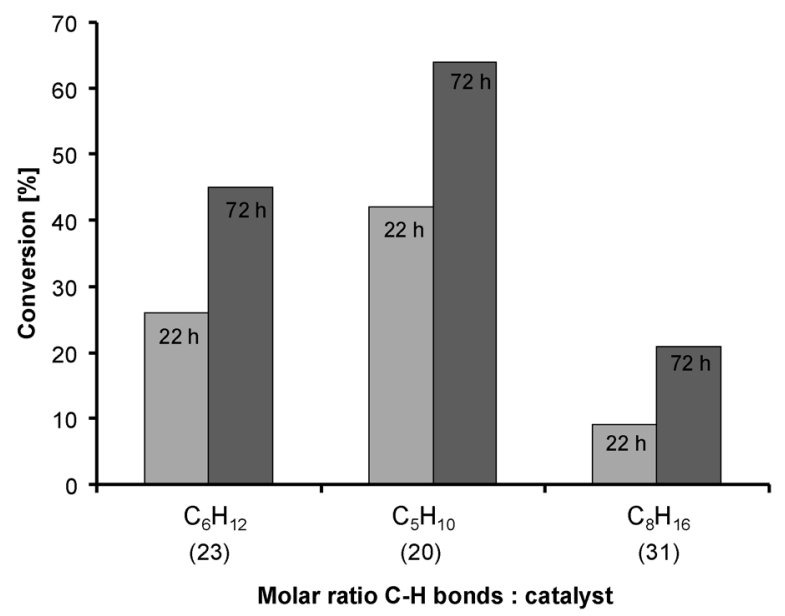

Figure 3. Deuteration (\% conversion) of $\mathrm{C}-\mathrm{H}$ bonds after $\mathrm{H} / \mathrm{D}$ exchange between $\mathrm{C}_{6} \mathrm{D}_{6}(5.65 \mathrm{mmol})$ and cyclohexane, cyclopentane and cyclooctane $(0.95-1.00 \mathrm{mmol})$ after $22 \mathrm{~h}$ or $72 \mathrm{~h}$ at $40^{\circ} \mathrm{C}$ in the presence of ACF $(0.5 \mathrm{mmol})$

The scope of the method is not restricted to cyclohexane. Cyclopentane, cyclooctane and hexamethylethane can also be deuterated in the presence of $\mathrm{ACF}$ at $40{ }^{\circ} \mathrm{C}$ with $42 \%$, $9 \%$, and $18 \%$ deuterium incorporation into the alkanes, respectively (Figure 3). A higher deuteration of cyclohexane, cyclopentane and cyclooctane was achieved after prolonged reaction times. Thus, $45 \%, 64 \%$, and $21 \%$ deuterium incorporation were obtained after $72 \mathrm{~h}$ at $40^{\circ} \mathrm{C}$, respectively.

Mechanistically, we presume that in an initial step the $\mathrm{C}^{-}$ $\mathrm{H} / \mathrm{D}$ bonds in the organic substrates RH interact via the $\sigma$ bond with a Lewis acidic surface site at the ACF or HS- 


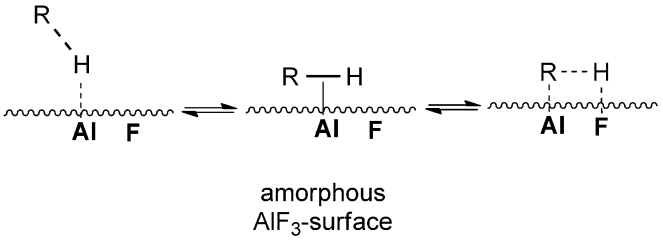

Figure 4. $\mathrm{C}-\mathrm{H}$ activation on bifunctional Lewis-acidic $\mathrm{HS}-\mathrm{AlF}_{3}$ or $\mathrm{ACF}$ surface sites. $\mathrm{R}=$ alkyl, aryl

$\mathrm{AlF}_{3}$ (Figure 4). ${ }^{[46]}$ It has been shown that both aluminium fluoride phases exhibit a huge number of under-coordinated Al surface sites that define the Lewis acidic properties of these catalysts. ${ }^{[45]}$ After coordination the $\mathrm{C}-\mathrm{H} / \mathrm{D}$ bonds are further activated as the consequence of an interaction of a neighboured fluoride with the H/D atom, which is presumably positively charged. ${ }^{[47]}$ This leads to Al-bound organyl moieties that are carbanionic in character. The presence of adjacent $\mathrm{F} \cdots \mathrm{D}-\mathrm{R}$ and $\mathrm{F} \cdots \mathrm{H}-\mathrm{R}$ sites results in $\mathrm{H} / \mathrm{D}$ exchange via reversible $\mathrm{C}-\mathrm{H} / \mathrm{C}-\mathrm{D}$ bond-forming reactions (Figure 4). Under-coordinated aluminium sites on the catalyst surface have also been discussed for $\mathrm{C}-\mathrm{H}$ activation on $\mathrm{Al}_{2} \mathrm{O}_{3}$ surfaces to give $\mathrm{Al}-\mathrm{C}$ bonds. ${ }^{[38 c, 48,49]}$ For instance Copéret and Sautet et al. attributed $\mathrm{CH}_{4} / \mathrm{D}_{2}$ exchange reactions at $\gamma$ $\mathrm{Al}_{2} \mathrm{O}_{3}$ to its surface Lewis acidity and proposed intermediate $\mathrm{Al}-\mathrm{CH}_{3}$ and $\mathrm{OH}$ moieties. ${ }^{[38 c, 48]}$

An alternative mechanism would involve cationic-like species. Thus, intermediate surface-bound cationic entities reminiscent of carbenium and phenyl cations might be generated by certain surface Lewis acidic sites via an aluminium hydrogen interaction (Figure 4) ${ }^{[50]}$ However, for the deuteration of toluene, which occurs at the aromatic ring (see above), one would then expect a preference for the activation of the methyl group via a species which resembles a benzyl cation. Note that we have no indication for FriedelCrafts chemistry. ${ }^{[51]}$ Yet, we can't exclude traces of adventitious water that could generate strong Brønsted acidic sites by interaction with the surface. These would induce an H/D exchange via protonation.

Nonetheless, the rearrangement of cyclohexane can be rationalized by the formation of surface-adsorbed carbocationic species. At $40^{\circ} \mathrm{C}$ in the presence of $\mathrm{HS}-\mathrm{AlF}_{3}$ or $\mathrm{ACF}$, cyclohexane was converted into methylcyclopentane $(11 \%)$. On using methylcyclopentane, we found a very similar product distribution of $87 \%$ cyclohexane and $13 \%$ methylcyclopentane, which suggests a rapid establishment of the equilibrium. ${ }^{[52]}$

Please note that the Lewis acidic surface sites at ACF or $\mathrm{HS}-\mathrm{AlF}_{3}$ are characterized by a dissimilar Lewis acidity as was shown by FT-IR spectroscopic determination of adsorbed $\mathrm{CO}$ molecules. ${ }^{[42]}$ However, it is unclear which strength of Lewis acidity is needed to induce a C-H/D activation step. Thus, it is very likely that only a fraction of the Lewis acidic surface acts catalytically.

In conclusion, highly Lewis acidic $\mathrm{ACF}$ and $\mathrm{HS}-\mathrm{AlF}_{3}$ are suitable catalysts for $\mathrm{C}-\mathrm{H} / \mathrm{D}$ bond activation, which enable efficient $\mathrm{H} / \mathrm{D}$ exchange reactions at exceptionally mild con- ditions $\left(40^{\circ} \mathrm{C}\right)$. A high degree of deuterium incorporation into benzene and cycloalkanes has been achieved. However, the reactions are reversible, which implies that for a synthesis of highly deuterated alkanes a large excess of the deuterated substrate is needed. Note that for industrial applications, deuterated decaline can be synthesized on using $\mathrm{D}_{2}$ or $\mathrm{D}_{2} \mathrm{O}$ as substrate and $\mathrm{Pt} / \mathrm{C}$ as catalyst. ${ }^{[33]} \mathrm{High}$ conversion is obtained because the reactions are repeated under highpressure conditions up to eight times. Such conversions at non-precious metal catalysts may provide a new route to deuterated alkanes and arenes. Highly Lewis acidic surface sites as well as the presence of fluoride at the surface seem to be prerequisites for the $\mathrm{C}-\mathrm{H} / \mathrm{D}$ bond activation step. Therefore, the bifunctionality of these distorted aluminium fluoride phases is a crucial property. ${ }^{[54]}$

\section{Experimental Section}

All solvents were purified, dried and distilled under an argon atmosphere using conventional methods. Cyclohexane, cyclopentane, cyclooctane and $\left[D_{6}\right]$ benzene were dried by stirring over sodium potassium alloy and then distilled at atmospheric pressure. Benzene was dried over sodium, and toluene was dried by purification with the MBraun Solvent Purification System. $\mathrm{C}_{6} \mathrm{D}_{12}$ (dry in ampoule) and hexamethylethane were obtained from Sigma-Aldrich and used as received. The water content of both deuterium sources was determined by Karl-Fischer titration $\left(\mathrm{C}_{6} \mathrm{D}_{6}\right.$ : $18 \mathrm{ppm} ; \mathrm{C}_{6} \mathrm{D}_{12}: 34 \mathrm{ppm}$ ). Ultra-dry $\mathrm{AlCl}_{3}$ (ampoule) was obtained from Sigma-Aldrich and used as received. $\mathrm{ACF},{ }^{[39]}$ and $\mathrm{HS}-\mathrm{AlF}_{3},{ }^{[43]}$ were synthesised as previously reported.

Characteristic analytical data of $\mathbf{H S}-\mathbf{A l F}_{\mathbf{3}}$ and $\mathbf{A C F}$ : Surface size of ACF is $101 \mathrm{~m}^{2} \mathrm{~g}^{-1},{ }^{[40,45]}$ (BET); under-coordinated $\mathrm{Al}$ sites at the ACF surface were probed by ${ }^{27} \mathrm{Al}$ MAS NMR spectroscopy. ${ }^{[40]}$ The vacant $\mathrm{Al}$ sites are strongly acidic. This has been confirmed by $\mathrm{NH}_{3}$-TPD measurements ${ }^{[45]}$ and is supported by computational simulation. ${ }^{[0,55]} \mathrm{HS}-\mathrm{AlF}_{3}$ has a surface of $323 \mathrm{~m}^{2} \mathrm{~g}^{-1}$ (BET), ${ }^{[56]}$ a particle size of $5 \mathrm{~nm}\left(\mathrm{DLS}_{95 \%}\right)$ and $10 \mathrm{~nm}$ (TEM). ${ }^{[57]} \mathrm{HS}-\mathrm{AlF}_{3}$ contains $0.978 \mathrm{mmolg}^{-1[50 \mathrm{a}]}$ acidic sites similar to ACF as determined by $\mathrm{NH}_{3}$-TPD. ${ }^{[45]} \mathrm{CO}$ FTIR measurements indicate the presence of the strongest Lewis sites ever detected at solid surfaces. $^{[42]}$

The NMR spectra were recorded at $300 \mathrm{~K}$ on a Bruker DPX 300 NMR spectrometer. All reactions were prepared in an argon-filled glovebox. The reactions were performed in Teflon-capped Young valve NMR tubes, which were kept at the indicated temperatures for $22 \mathrm{~h}$. Selected catalytic experiment: (Figure 1): ACF ( $43 \mathrm{mg}, 0.5 \mathrm{mmol}$ ) was filled into a Young valve NMR tube, followed by the addition of benzene $(100 \mu \mathrm{L}$, $85 \mathrm{mg}, 1.12 \mathrm{mmol})$ and $\mathrm{C}_{6} \mathrm{D}_{12}(500 \mu \mathrm{L}, 447 \mathrm{mg}, 4.63 \mathrm{mmol})$. The reaction mixture was kept at $110^{\circ} \mathrm{C}$ for $22 \mathrm{~h}$. Then the NMR tube was cooled to room temperature and the conversion was determined by ${ }^{1} \mathrm{H}$ NMR spectroscopy using hexamethyldisilane $(20 \mu \mathrm{L})$ as standard. The deuterium incorporation was qualitatively verified by ${ }^{2} \mathrm{H} \mathrm{NMR},{ }^{13} \mathrm{CNMR}$ and $\mathrm{MS}$ analysis (see Supporting Information for spectra and further information).

\section{Acknowledgements}

We thank the Alexander-von-Humboldt Foundation (M. H. G. P.) for financial support, and Dr. R. König and Dr. S. R. Manuel for the synthesis of $\mathrm{HS}-\mathrm{AlF}_{3}$. We also acknowledge the GRK 1582 "Fluorine as Key Element". 
Keywords: aluminium fluorides • bifunctional catalysts $\mathrm{C}-\mathrm{H}$ activation $\cdot \mathrm{H} / \mathrm{D}$ exchange $\cdot$ Lewis acids

[1] J. T. Golden, R. A. Andersen, R. G. Bergman, J. Am. Chem. Soc. 2001, 123, 5837-5838.

[2] T. Junk, W. J. Catallo, Chem. Soc. Rev. 1997, 26, 401-406.

[3] S. R. Klei, J. T. Golden, T. D. Tilley, R. G. Bergman, J. Am. Chem. Soc. 2002, 124, 2092-2093.

[4] H. Lowry, K. S. Richardson, Mechanism and Theory in Organic Chemistry, Harper and Row, New York, 1987.

[5] A. F. Thomas, Deuterium Labelling in Organic Chemistry, Meridith Cooperation, New York, 1971.

[6] C. M. Yung, M. B. Skaddan, R. G. Bergman, J. Am. Chem. Soc. 2004, 126, 13033-13043.

[7] J. Atzrodt, V. Derdau, T. Fey, J. Zimmermann, Angew. Chem. 2007, 119, 7890-7911; Angew. Chem. Int. Ed. 2007, 46, 7744-7765.

[8] V. Derdau, J. Atzrodt, J. Zimmermann, C. Kroll, F. Bruckner, Chem. Eur. J. 2009, 15, 10397-10404.

[9] T. Maegawa, Y. Fujiwara, Y. Inagaki, H. Esaki, Y. Monguchi, H. Sajiki, Angew. Chem. 2008, 120, 5474-5477; Angew. Chem. Int. Ed. 2008, 47, 5394-5397.

[10] Y. Suzuki, T. Korenaga, Y. Chikaraishi, Chem. Lett. 2006, 35, $532-$ 533.

[11] C. C. Tong, K. C. Hwang, J. Phys. Chem. C 2007, 111, 3490-3494.

[12] M. Yamamoto, Y. Yokota, K. Oshima, S. Matsubara, Chem. Commun. 2004, 1714-1715.

[13] T. Kaino, K. Jinguji, S. Nara, Appl. Phys. Lett. 1983, 42, 567-569.

[14] A. J. Hickman, J. M. Villalobos, M. S. Sanford, Organometallics 2009, 28, 5316-5322.

[15] S. K. Meier, K. J. H. Young, D. H. Ess, W. J. Tenn, J. Oxgaard, W. A. Goddard, R. A. Periana, Organometallics 2009, 28, 5293-5304.

[16] M. H. G. Prechtl, M. Holscher, Y. Ben-David, N. Theyssen, R. Loschen, D. Milstein, W. Leitner, Angew. Chem. 2007, 119, 2319-2322; Angew. Chem. Int. Ed. 2007, 46, 2269-2272.

[17] M. H. G. Prechtl, M. Holscher, Y. Ben-David, N. Theyssen, D. Milstein, W. Leitner, Eur. J. Inorg. Chem. 2008, 3493-3500.

[18] a) J. M. Villalobos, A. J. Hickman, M. S. Sanford, Organometallics 2010, 29, 257-262; b) A. Di Giuseppe, R. Castarlenas, J. J. PérezTorrente, V Polo, L. A. Oro, Angew. Chem. 2011, 123, 4024-4028; Angew. Chem. Int. Ed. 2011, 50, 3938-3942.

[19] F. Kakiuchi, S. Murai, Acc. Chem. Res. 2002, 35, 826-834

[20] L. S. Ott, M. L. Cline, M. Deetlefs, K. R. Seddon, R. G. Finke, J. Am. Chem. Soc. 2005, 127, 5758-5759.

[21] M. H. G. Prechtl, Y. Ben-David, D. Giunta, S. Busch, Y. Taniguchi, W. Wisniewski, H. Gorls, R. J. Mynott, N. Theyssen, D. Milstein, W. Leitner, Chem. Eur. J. 2007, 13, 1539-1546.

[22] B. Rybtchinski, R. Cohen, Y. Ben-David, J. M. L. Martin, D. Milstein, J. Am. Chem. Soc. 2003, 125, 11041-11050.

[23] S. Sabo-Etienne, B. Chaudret, Coord. Chem. Rev. 1998, 178, 381407.

[24] J. D. Scholten, J. Dupont, Organometallics 2008, 27, 4439-4442.

[25] J. R. Zhou, J. F. Hartwig, Angew. Chem. 2008, 120, 5867-5871; Angew. Chem. Int. Ed. 2008, 47, 5783-5787.

[26] G. A. Olah, A. Molnar, S. K. Prakash, J. Sommer, Superacid Chemistry, Wiley, New York, 2009.

[27] G. A. Olah, S. K. Prakash, R. E. Williams, L. D. Field, K. Wade, Hypercarbon Chemistry, Wiley, New York, 1987.

[28] M. Lersch, M. Tilset, Chem. Rev. 2005, 105, 2471-2526.

[29] A. E. Shilov, G. B. Shul'pin, Chem. Rev. 1997, 97, 2879-2932.

[30] see also: R. Palkovits, M. Antonietti, P. Kuhn, A. Thomas, F. Schüth, Angew. Chem. 2009, 121, 7042-7045; Angew. Chem. Int. Ed. 2009, 48, 6909-6912.

[31] J. Engelhardt, W. K. Hall, J. Catal. 1995, 151, 1-9.
[32] J. Engelhardt, G. Onyestyak, W. K. Hall, J. Catal. 1995, 157, 721729.

[33] M. Haouas, G. Fink, F. Taulelle, J. Sommer, Chem. Eur. J. 2010, 16, 9034-9039.

[34] S. G. Hindin, G. A. Mills, A. G. Oblad, J. Am. Chem. Soc. 1951, 73, $278-281$.

[35] B. Schoofs, J. Schuermans, R. A. Schoonheydt, Microporous Mesoporous Mater. 2000, 35-6, 99-111.

[36] J. Sommer, M. Hachoumy, F. Garin, D. Barthomeuf, J. Vedrine, J. Am. Chem. Soc. 1995, 117, 1135-1136.

[37] J. Sommer, R. Jost, M. Hachoumy, Catal. Today 1997, 38, 309-319.

[38] a) J. G. Larson, W. K. Hall, J. Phys. Chem. 1965, 69, 3080-3089; b) P. J. Robertson, M. S. Scurrell, C. Kemball, J. Chem. Soc. Faraday Trans. 1975, 71, 903-912; c) R. Wischert, C. Copéret, F. Delbecq, P. Sautet, Angew. Chem. 2011, 123, 3260-3263; Angew. Chem. Int. Ed. 2011, 50, 3202-3205.

[39] T. Krahl, E. Kemnitz, J. Fluorine Chem. 2006, 127, 663-678.

[40] T. Krahl, R. Stößer, E. Kemnitz, G. Scholz, M. Feist, G. Silly, J. Y. Buzare, Inorg. Chem. 2003, 42, 6474-6483.

[41] R. König, G. Scholz, K. Scheurell, D. Heidemann, I. Buchem, W. E. S. Unger, E. Kemnitz, J. Fluorine Chem. 2010, 131, 91-97.

[42] T. Krahl, A. Vimont, G. Eltanany, M. Daturi, E. Kemnitz, J. Phys. Chem. C 2007, 111, 18317-18325.

[43] S. Rüdiger, G. Eltanany, U. Gross, E. Kemnitz, J. Sol-Gel Sci. Technol. 2007, 41, 299-311.

[44] The exact conversion cannot be determined, due to a slight overlap of the ${ }^{1} \mathrm{H}$ NMR signals of partly deuterated toluene and benzene.

[45] J. K. Murthy, U. Gross, S. Rudiger, V. V. Rao, V. V. Kumar, A. Wander, C. L. Bailey, N. M. Harrison, E. Kemnitz, J. Phys. Chem. B 2006, 110, 8314-8319.

[46] C. Hall, R. N. Perutz, Chem. Rev. 1996, 96, 3125-3146.

[47] Note that the interaction of fluorides with $\mathrm{C}-\mathrm{H}$ bonds has been described in the literature: a) V. V. Grushin, Acc. Chem. Res. 2010, 43, 160-171; b) D. Noveski, T. Braun, B. Neumann, A. Stammler, H.-G. Stammler, Dalton Trans. 2004, 4106-4119; c) G. Meier, T. Braun Angew. Chem. 2011, 123, 3338-3342; Angew. Chem. Int. Ed. 2011 $50,3280-3284$.

[48] a) C. Coperet, Chem. Rev. 2010, 110, 656-680; b) J. Joubert, A. Salameh, V. Krakoviack, F. Delbecq, P. Sautet, C. Copéret, J. M. Basset, J. Phys. Chem. B 2006, 110, 23944-23950.

[49] E. Iglesia, D. G. Barton, J. A. Biscardi, M. J. L. Gines, S. L. Soled, Catal. Today 1997, 38, 339-360.

[50] a) K. Teinz, S. Wuttke, F. Börno, J. Eicher, E. Kemnitz, J. Catal. 2011, 282, 175-182; b) H. Förster, I. Kiricsi, G. Tasi, I. Hannus, $J$. Mol. Struct. 1993, 296, 61-67.

[51] a) G. A. Olah, C. S. Lee, G. K. S. Prakash, R. M. Morirty, M. S. C. Rao, J. Am. Chem. Soc. 1993, 115, 10728-10732; b) J. T. Mague, L. Linhardt, I. Medina, D. J. Sattler, M. J. Fink, Acta Cryt. E 2008, E64, o375.

[52] D. P. Stevenson, O. Beeck, J. Am. Chem. Soc. 1948, 70, 2890-2894.

[53] a) G. Möbius, G. Schaaf, 1984, DD 279376; b) G. Möbius, G. Schaaf, 1984, DD25970484; c) H. Sajikii, T. Maegawa, Y. Minguchi, 2008, WO 066158

[54] D. Erdogan, D. B. Grotjahn, J. Am. Chem. Soc. 2009, 131, $10354-$ 10355 .

[55] K. O. Christe, D. A. Dixon, D. McLemore, W. W. Wilson, J. A. Sheehy, J. A. Boatz, J. Fluorine Chem. 2000, 101, 151-153.

[56] S. M. Coman, P. Patil, S. Wuttke, E. Kemnitz, Chem. Commun. 2009, 7597-7597.

[57] G. Eltanany, PhD thesis, Humboldt Universität zu Berlin (Berlin), 2007.

Received: September 13, 2011 Published online: November 29, 2011 